\title{
Applications of Planned Behavior Theory (TPB) in Jordanian Tourism
}

\author{
Mamdouh T. AL Ziadat ${ }^{1}$ \\ ${ }^{1}$ College of Economic and Administrative Sciences, Applied Science University, Jordan \\ Correspondence: Mamdouh T. AL Ziadat, College of Economic and Administrative Sciences, Applied Science \\ University, Amman, Jordan. E-mail: aied_muala@yahoo.com
}

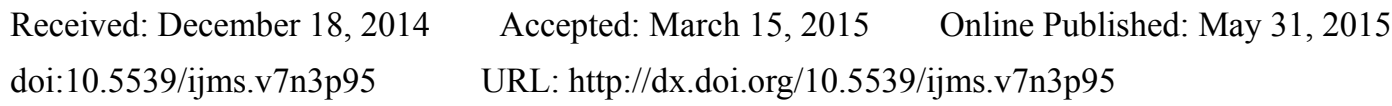

\begin{abstract}
This study tested the sufficiency and application of the Theory of Planned Behavior (TPB) in tourism of Jordan by examining the antecedents of revisit intention/actual visit behavior, and the mediating effect of revisit intention in the relationship between perceived behavior control (PBC) and actual visit behavior (ACT). This study used a survey data of 403 international tourists who visited Jordan. Confirmatory Factor Analysis (CFA) was performed to examine the reliability and validity of the measurement, and the structural equation modeling techniques (Amos 20) were used to evaluate the casual model. Results of the study demonstrate the strong predictive power of the original TPB model to explain international tourists' behavior in Jordan. The findings highlighted that the relationship between tourist attitude and subjective norm are significant and positive on revisit intention. In addition, revisit intention and perceived behavior control are significant and show positive direct impacts on actual visit behavior. In contrast, perceived behavior control yields insignificant impact on revisit intention. Revisit intention however, does not have mediating effect in the relationship between perceived behavior control and actual visit behavior.
\end{abstract}

Keywords: Theory of planned behavior (TPB), actual visit behavior, revisit intention, tourists attitude, subjective norms, perceived behavior control

\section{Introduction}

Travel and tourism have become a global industry. Tourism industry has grown at an amazing pace since the last decades and become one of the largest industries in the world (Hui et al., 2007). Understanding tourists' behavior is crucial for both tourists and destinations. Due to the importance of this industry to a country's economy, its tourism ministry has been urged to understand the tourists' behavior and the plausible factors that might influence their travelling decision. This imperative need of understanding tourists' behavior also becomes one of the major concerns of the Jordanian tourism ministry.

Tourists' behavior has always been a central issue in the tourism literature (Wong \& Yeh, 2009). Most studies are related to the loyalty of the tourists which centered on tourist satisfaction on the services being provided particularly in the western context (Riley et al., 2001). Apparently, there is limited empirical investigation to verify the causal antecedents of actual visit behavior in Arab countries particularly Jordan.

\section{Literature Review}

Tourists, one important factor in the tourism industry Arabic. We must find out more information about the behavior of foreign tourists and what are their expectations for services prior to their departure from their country. Therefore, the behavior of tourists who make the purchasing decisions (Al Muala, 2011)

Based on this implication, the present study undertook the initiative to further investigate the application of the theory of planned behavior (TPB) in tourism of Jordan by examining the antecedents of revisit intention/actual visit behavior, and the mediating effect of revisit intention in the relationship between perceived behavior control (PBC) and actual visit behavior (ACT) among the tourists. The main components of the TPB are a person's own attitude, subjective norms, perceived behavioral control, intentions, and behavior (Ajzen, 1988).

The relations among these variables are described in (Figure 1). TPB hypothesizes that individual behavior is driven by behavioral intentions while behavioral intentions are a function of a tourist's attitude toward the behavior. Attitude toward the behavior is defined as the individual's positive or negative feelings about performing behavior McIvor and Paton (2007). Behavioral intention is a sign of a tourist's readiness to carry out certain conducts or 
behaviors. According to TPB, a tourist's performance of a certain behavior is determined by his or her intent to perform that behavior (see Figure 1).

For TPB, tourist's attitude (ATT) towards the target behavior, subjective norms (SN) about engaging in the behavior, and perceived behavior control (PBC) are thought to influence revisit intention (INT) and actual visit behavior (ACT). Perceived behavioral control (PBC) is informed by beliefs about the tourist's possession of the opportunities and resources needed to engage in the behavior (Ajzen, 1991).TPB has been used in many different studies such as Internet purchasing behavior (Celik, 2008; George, 2002; Jarvenpaa \& Todd, 1997; Limayen and Khalifa 2003) and in information systems literature (Mathieson, 1991; Taylor \& Todd, 1995). However, due to its contextual settings, the TPB model could contain Western cultural biases (Javalgi et al., 2005). Besides, there is limited empirical study on TPB in Arab countries specifically in Jordan.

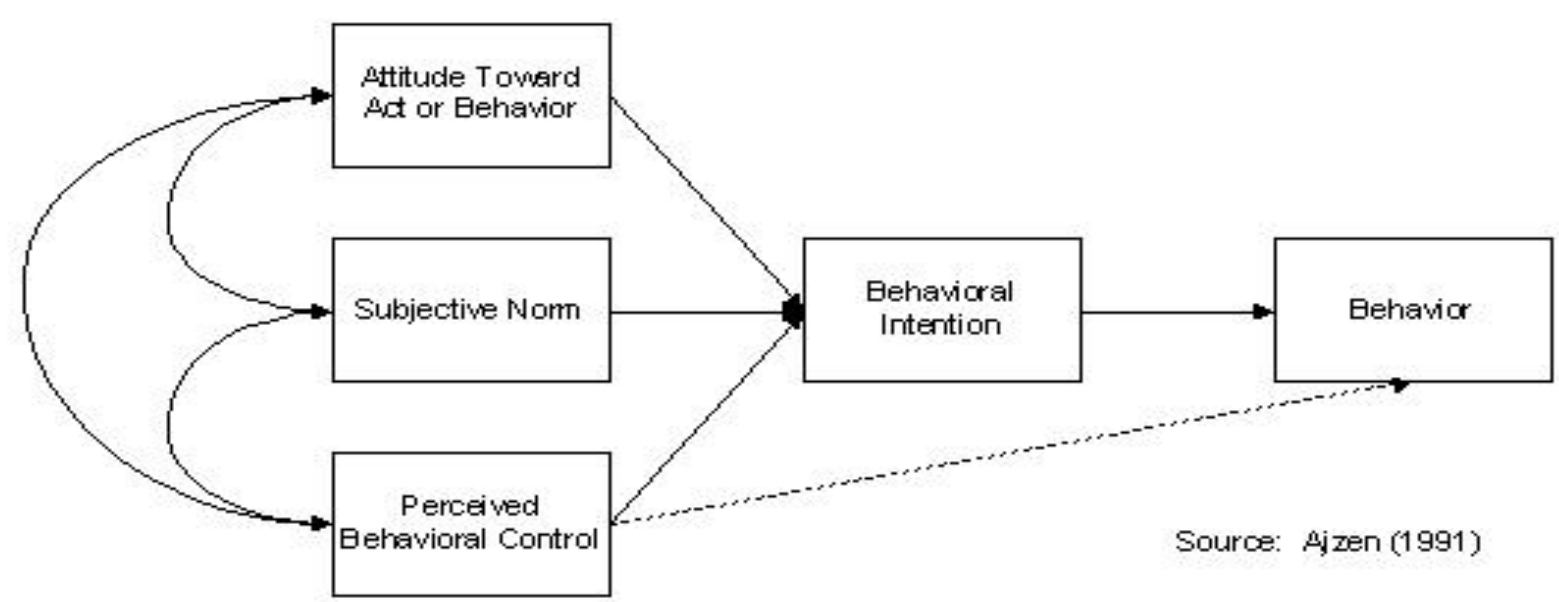

Figure 1. Theory of planned behavior (TPB)

\section{Methodology}

This study chose a systematic random sample in which 403 respondents were identified from 20 hotels in the middle region of Jordan. The sampling frame for this study consisted of international tourists, who stayed in hotels during their visit to Jordan in the period from November 10, 2013 and until December 20, 2013. Out of 403 questionnaires distributed, 55 were undelivered, and 45 questionnaires were incomplete (missing responses). Thus, a total of 304 responses were usable and used for subsequent analysis, giving a response rate of $75 \%$. The questionnaire is divided into four parts: (1) demographic variables (12 items); (2) tourist attitude (6 items), subjective norm (6 items) and perceived behavior control (6 items), and all items were adapted from Cannier et al. (2008); (3) revisit intention 5 items adapted from Al Muala et al. (2012); and (4) Actual visit Behavior (5 items) which were adapted Shih, 2004 and Raman (2008).

\subsection{Hypotheses Formulation}

Based on the objective of the study, six hypotheses were developed:

H1 Revisit Intention is positively related with Actual visit Behavior.

H2 Tourist Attitude is positively related with Revisit Intention.

H3 Subject Norm is positively related with Revisit Intention.

H4 Perceived Behavior Control is positively related with Revisit Intention.

H5 Perceived Behavior Control positively related with Actual visit Behavior.

H6 Revisit Intention mediates the relationship between Perceived Behavior Control and Actual visit Behavior.

\section{Results}

\subsection{Demographic Profile of the Respondents}

The respondents' ages ranged from 20 to more than 50 years old. There were slightly more male $(66.6 \%)$ than female respondents (33.4\%). The majority of the respondents are married $64.4 \%$, and $26.7 \%$ are singles. The 
tourists came from the European countries (37.9\%), followed by Africa (25.7\%), Asia (17.6\%), Australia (3.4\%), and Russia (0.8\%). Most of them work in public sector $(39.7 \%)$, whilst $21.9 \%$ work in private sectors. The majority of income level is less than 1000 USD. Most tourists spent less than USD100 (63.6\%), followed by between USD101 to $200(32.6 \%)$ and more than USD 200 (3.8\%). The main reason for visiting Jordan is for relaxation $(68.2 \%)$, medical treatment $(11.3 \%)$, and others $(20.5 \%)$. The majority of them stayed in hotels $(53.2 \%)$ within the duration period between 2 to 10 days (84.2\%). They came to Jordan via air (50.6\%), sea (26.1) and land route $(23.3 \%)$, either by using tourists' coaches $(25.7 \%)$, rental car $(25.1 \%)$, taxi $(20.6 \%)$, public transportation $(10.7 \%)$ and others $(17.8 \%)$.

\subsection{Descriptive Analysis of Variables}

The research framework consists of three exogenous (tourist attitude, subjective norm, and perceived behavior control) and two endogenous variables (revisit intention and actual visit behavior) (Table 1). Each construct shows Cronbach alpha readings of acceptable values of above 0.60 (Nunnally, 1970).

Table 1. Descriptive statistics of variables

\begin{tabular}{|c|c|c|c|c|c|c|}
\hline Construct & $\begin{array}{l}\text { Original } \\
\text { Items }\end{array}$ & $\begin{array}{l}\text { Total } \\
\text { Mean }\end{array}$ & $\begin{array}{l}\text { Standard } \\
\text { Deviation }\end{array}$ & $\begin{array}{l}\text { Items after } \\
\text { CFA }\end{array}$ & $\begin{array}{l}\text { Cronbach } \\
\text { Alpha after } \\
\text { CFA }\end{array}$ & $\begin{array}{l}\text { Composite } \\
\text { Reliability }\end{array}$ \\
\hline Tourist Attitude & 6 & 6.09 & .604 & 4 & .82 & .90 \\
\hline Revisit Intention & 5 & 6.04 & .751 & 4 & .88 & .91 \\
\hline Subject Norm & 6 & 5.92 & .792 & 4 & .85 & .93 \\
\hline Perceived Behavior Control & 6 & 5.68 & .718 & 4 & .60 & .87 \\
\hline Actual visit behavior & 5 & 5.33 & .772 & 4 & .61 & .78 \\
\hline
\end{tabular}

\subsection{Confirmatory Factor Analysis (CFA) Results}

Table 2. Final confirmatory factor analysis results of construct variables

\begin{tabular}{|c|c|c|c|}
\hline Variables & Code & Attributes & $\begin{array}{l}\text { Factor } \\
\text { Loading }\end{array}$ \\
\hline Tourist & ATT 1 & - $\quad$ I Visiting Jordan to me is Exciting. & .81 \\
\hline \multirow[t]{3}{*}{ Attitude } & ATT 2 & - Visiting Jordan to me is Important. & .80 \\
\hline & ATT 3 & - Visiting Jordan to me is Pleasant. & .80 \\
\hline & ATT 5 & - $\quad$ Visiting Jordan to me is A good idea & .53 \\
\hline \multirow{5}{*}{$\begin{array}{l}\text { Subject } \\
\text { Norm }\end{array}$} & SN 2 & - $\quad$ Friends who influence my behavior consider it a good idea if we visit Jordan at least & .78 \\
\hline & & once in the near future. & \\
\hline & SN 3 & - $\quad$ Friends who influence my behavior will visit Jordan at least once in the near future. & .92 \\
\hline & SN 4 & - $\quad$ My friends approve that I visit Jordan at least once in a life time. & .79 \\
\hline & SN 6 & $\begin{array}{l}\text { - Family members who influence my behavior approve that I visit Jordan in the near } \\
\text { future. }\end{array}$ & .55 \\
\hline Perceived & PBC 1 & - I fully depend on me whether I will visit Jordan at least once in the near future. & .75 \\
\hline Behavior & PBC 2 & - I fully control the fact that I visit Jordan at least once in the near future. & .73 \\
\hline \multirow[t]{2}{*}{ Control } & PBC 3 & - $\quad$ During my visit to Jordan I felt confused. & .59 \\
\hline & PBC 4 & - $\quad$ During my visit to Jordan I felt calm. & .72 \\
\hline Revisit & INT 2 & - I would like to stay in Jordan again if I have another chance in future. & .71 \\
\hline \multirow[t]{3}{*}{ Intention } & INT 3 & - I intend to revisit Jordan again in the future. & .80 \\
\hline & INT 4 & - I am willing to pay more for vacationing in Jordan in the future. & .86 \\
\hline & INT 5 & - I am willing to visit Jordan more frequently. & .85 \\
\hline Actual Visit & ACT 1 & - I find visiting of Jordan is useful and enjoyment for me. & .59 \\
\hline \multirow[t]{3}{*}{ Behavior } & ACT 2 & - I believe visiting of Jordan is an easy and safe way to visit Arab countries. & .61 \\
\hline & ACT 4 & - I feel fast and easy access to services and transportation during visiting Jordan. & .59 \\
\hline & ACT 5 & - $\quad$ Many times I visited Jordan. & .46 \\
\hline Total & 20 & & \\
\hline
\end{tabular}


From the confirmatory factor analysis result in Table 2, we observed that the factor loadings of all observed variables or items are adequate ranging from 0.46 to 0.92 . In this study, the "cut-off" point chosen for significant loading is 0.30 , the minimum level required for a sample size of 350 and above as suggested by (Hair et al. 2006, p 128). This indicates that all the constructs conform to the construct validity test. As shown in Table 2, the remaining numbers of items for each construct are as follows: Attitude (4 items), Subjective norms (4 items), Perceived behavior control (4 items), intention ( 4 items), and actual visit behavior (4 items), and the totals of items are 20.

\subsection{Discriminant Validity of Constructs}

Discriminant validity refers to observed of constructs that should not be related to each other. In short, observed to not be related to each other (Campbell \& Fiske, 1959). Table 3 shows the result of the calculated variance extracted (VE) to support discriminant validity of constructs. Average variance extracted (AVE) is the average VE values of two constructs (Table 4). The AVE derived from the calculation of variance extracted using the following equation:

$$
\text { Variance Extracted }=\frac{\sum\left(s \tan \text { dardized } S M C^{2}\right)}{\sum\left(s \tan \text { dardized } S M C^{2}\right)+\varepsilon \sum j}
$$

According to Fornell \& Larcker (1981), average variance extracted (AVE) should be more than the correlation squared of the two constructs to support discriminant validity (compare Table 4 and Table 5). Each AVE value is found to be more than correlation square, thus discriminant validity is supported or Multicollinearity is absent.

Table 3. Variance extracted of variables

\begin{tabular}{lllll}
\hline Observed Variables & SMC & SMC 2 & Measurement Error & Variance Extracted \\
\hline PATT 2 & .75 & .56 & .086 & \\
PATT 3 & .54 & .29 & .065 & $\mathbf{. 8 5}$ \\
Tourist Attitude (total) & $\mathbf{1 . 2 9}$ & $\mathbf{. 8 5}$ & $\mathbf{. 1 5 1}$ & \\
PSN 3 & .81 & .66 & .066 & $\mathbf{. 9 0}$ \\
PSN 4 & .65 & .42 & .052 & \\
Subject Norm (total) & $\mathbf{1 . 4 6}$ & $\mathbf{1 . 0 6}$ & $\mathbf{. 1 1 8}$ & \\
BC 1 & .60 & .36 & .091 & $\mathbf{. 7 8}$ \\
BC 2 & .54 & .29 & .083 & \\
Perceived Behavior Control (total) & $\mathbf{1 . 1 4}$ & $\mathbf{. 6 5}$ & $\mathbf{. 1 8 0}$ & \\
RINT 2 & .68 & .46 & .069 & $\mathbf{. 8 7}$ \\
RINT 3 & .65 & .42 & .064 & \\
Revisit Intention (total) & $\mathbf{1 . 3 3}$ & $\mathbf{. 8 8}$ & $\mathbf{. 1 3 3}$ & \\
ACT 2 & .35 & .12 & .105 & $\mathbf{. 5 5}$ \\
ACT 4 & .38 & .14 & .107 & $\mathbf{. 2 1 2}$ \\
Actual Visit Behavior (total) &. $\mathbf{7 3}$ & $\mathbf{. 2 6}$ & & \\
\hline
\end{tabular}

Note. Code after transformation of constructs; PATT, PSN, RINT, BC.

Table 4. Average variance extracted (AVE) matrix of exogenous variables

\begin{tabular}{llllll}
\hline Variable Name & ATT & SN & PBC & INT & ACT \\
\hline ATT & 1 & & & & \\
SN & .88 & 1 & & & \\
PBC & .82 & .84 & 1 & & \\
INT & .86 & .89 & .83 & 1 & \\
ACT & .70 & .73 & .67 & .71 & 1 \\
\hline
\end{tabular}

Table 5. Correlation \& correlation square matrix among exogenous variables

\begin{tabular}{llllll}
\hline Variable Name & ATT & SN & PBC & INT & ACT \\
\hline ATT & 1 & & & & \\
SN & $.527(.28)$ & 1 & & & \\
PBC & $.551(.30)$ & $.539(.29)$ & 1 & & \\
INT & $.535(.29)$ & $583(.34)$ & $.482(.23)$ & 1 & \\
ACT & $.529(.28)$ & $.639(.41)$ & $.478(.23)$ & $.645(.42)$ & 1 \\
\hline Correlation is significant at 0.01 level (2-tailed), values in brackets indicate correlation squared.
\end{tabular}




\subsection{Goodness of Fit Indices}

Confirmatory factor analysis was conducted on every construct and measurement models (see Table 6). All CFAs of constructs produced a relatively good fit as indicated by the goodness of fit indices such as CMIN/df ratio $(<2)$; p-value ( $>0.05$ ); Goodness of Fit Index (GFI) of $>.95$; and root mean square error of approximation (RMSEA) of values less than $.08(<.08)$ (Hair et al., 2006). The measurement model has a good fit with the data based on assessment criteria such as GFI, CFI, TLI, RMSEA (Bagozzi and Yi, 1988). Table 6 shows that the goodness of fit of generated or re-specified model is better compared to the hypothesized model.

Table 6. Goodness of fit analysis-confirmatory factor analysis (CFA) $(\mathrm{N}=304)$

\begin{tabular}{|c|c|c|c|c|c|c|c|c|c|}
\hline Variables & $\begin{array}{l}\text { Tourist } \\
\text { Attitude }\end{array}$ & $\begin{array}{l}\text { Subjective } \\
\text { Norm }\end{array}$ & $\begin{array}{l}\text { Perceived } \\
\text { Behavior } \\
\text { Control }\end{array}$ & $\begin{array}{l}\text { Revisit } \\
\text { Intention }\end{array}$ & $\begin{array}{l}\text { Actual } \\
\text { Behavior }\end{array}$ & $\begin{array}{l}\text { Exogenous: } \\
\text { Attitude\& } \\
\text { Norm\& } \\
\text { perceived } \\
\text { behavior }\end{array}$ & $\begin{array}{l}\text { Endogenous: } \\
\text { Intention\& } \\
\text { Behavior }\end{array}$ & $\begin{array}{l}\text { Hypothesized } \\
\text { Model }\end{array}$ & $\begin{array}{l}\text { Generating } \\
\text { Model }\end{array}$ \\
\hline Items & 4 & 4 & 4 & 4 & 4 & 9 & 7 & 28 & 10 \\
\hline \multicolumn{10}{|l|}{ Remain } \\
\hline CMIN & 2.544 & 6.670 & 27.747 & 41.635 & 19.187 & 15.894 & 16.046 & 1202.875 & 35.962 \\
\hline DF & 2 & 2 & 2 & 2 & 2 & 11 & 13 & 342 & 26 \\
\hline CMIN/DF & 1.272 & 3.335 & 13.874 & 20.818 & 9.594 & 1.445 & 1.234 & 3.517 & 1.383 \\
\hline P-value & .0280 & 0.036 & 0.000 & 0.000 & 0.000 & 0.145 & 0.247 & 0.000 & 0.092 \\
\hline GFI & 0.997 & 0.994 & 0.975 & 0.958 & 0.982 & 0.991 & 0.991 & 0.845 & 0.986 \\
\hline CFI & 0.999 & 0.995 & 0.956 & 0.964 & 0.931 & 0.996 & 0.997 & 0.877 & 0.994 \\
\hline TLI & & 0.985 & 0.869 & 0.892 & 0.974 & 0.992 & 0.995 & 0.864 & 0.990 \\
\hline NFI & 0.997 & 0.993 & 0.953 & 0.962 & 0.925 & 0.987 & 0.984 & 0.836 & 0.980 \\
\hline RMSEA & 0.023 & 0.069 & 0.162 & 0.200 & 0.132 & 0.030 & 0.022 & 0.071 & 0.028 \\
\hline
\end{tabular}

\subsection{Hypotheses Results}

Since the hypothesized model (Figure 2 ) did not achieve model fit $(\mathrm{p}<.000)$, hence, the explanation of hypotheses result is based on Generating Model (GM) (Table 8 and Figure 3). Based on the finding, Table 8 decided three hypotheses significant through C.R. values and acceptable because they are above than +/-1.96 C.R (H1, H2, H3 and $\mathrm{H} 5$ ). In contrast there is one hypotheses (H4) did not have significant direct effects on revisit intention (critical ratio $(\mathrm{CR})<1.96 ; \mathrm{p}>.05)$. 


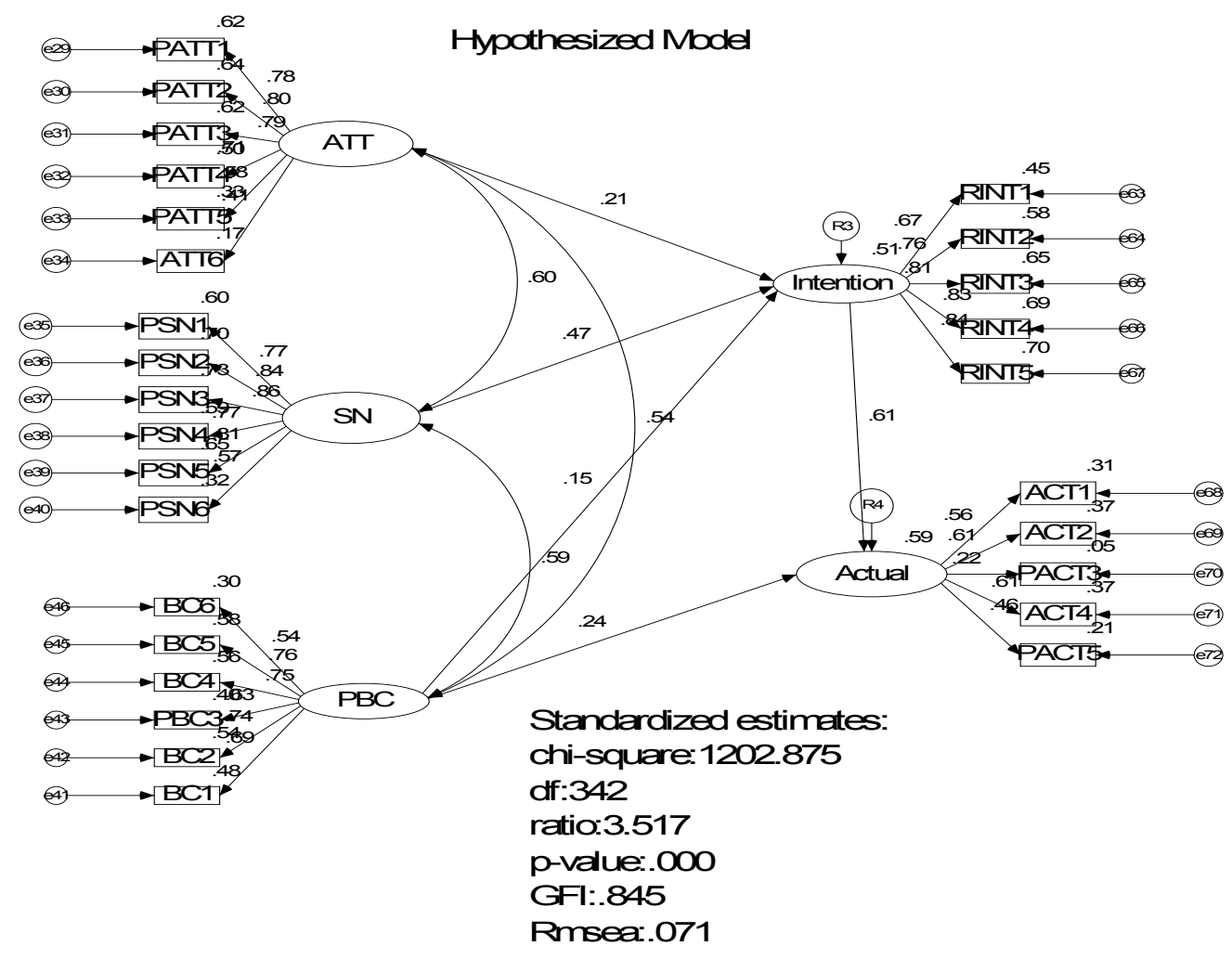

Figure 2. Hypothesized models (SC)

The Generating Model (GM) generates a new path to be directly influencing behavior:

Subjective norm to actual visit behavior (H3a), result found a positive relationship and significant C.R $>1.96$ and p-value $<.05$.

Table 7. Direct impact generating model (gm): standardized regression weights

\begin{tabular}{llllllll}
\hline H. & \multicolumn{2}{l}{ Regression Weights } & Estimate & SE & C.R. & P & $\begin{array}{l}\text { Hypothesis } \\
\text { support }\end{array}$ \\
\cline { 2 - 3 } & From & To & & & & & Y \\
H1 & INT & ACT & .449 & .252 & 3.880 & $* * *$ & Yes \\
H2 & ATT & INT & .181 & .068 & 2.863 & .004 & Yes \\
H3 & SN & INT & .531 & 0.094 & 6.280 & $* * *$ & Yes \\
H4 & PBC & INT & .072 & .070 & 1.128 & .259 & No \\
H5 & PBC & ACT & .229 & .239 & 2.298 & .022 & Yes \\
H3a (new path) & SN & ACT & .259 & .238 & 19.909 & $* * *$ & Yes \\
\hline
\end{tabular}

This structural path model result is depicted diagrammatically in Figure 3. Table 8 indicates that the three exogenous variables (attitude, subjective norms, and perceived behavior control) jointly explained $42.6 \%$ variance in intention. Subsequently, intention, attitude, subjective norm, perceived behavior control collectively explained $53.5 \%$ variance in behavior.

Table 8. Squared multiple correlation results

\begin{tabular}{ll}
\hline Endogenous Variable & Squared multiple correlation (SMC) $=$ R2 \\
\hline Revisit Intention & .426 \\
Actual Visit Behavior & .535 \\
\hline
\end{tabular}




\section{Generating Model}

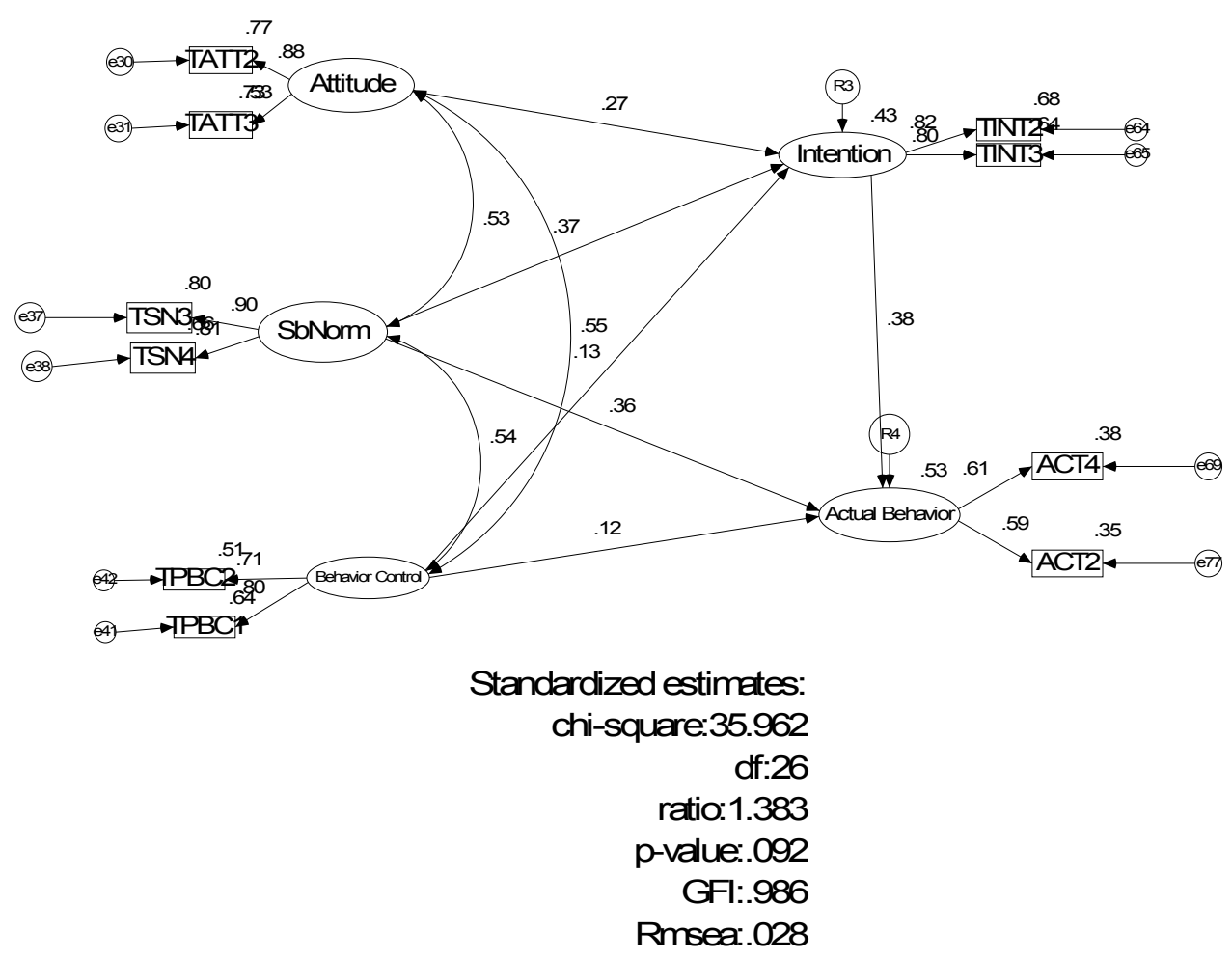

Figure 3. Generating model (GM)

\subsection{Mediating Effect Analysis of Generating Model (GM)}

A mediating effect is created when a third variable/construct intervenes between two other related constructs. Regarding to Generating Model (GM) there is one mediating effect of revisit intention, as show in Table 9, we tested the mediating effects of revisit intention in the relationship between perceived behavior control and revisit behavior.

Table 9. Mediating effect of revisit intention

\begin{tabular}{llllllll}
\hline Hypothesis & From & Mediation & To & $\begin{array}{l}\text { Direct } \\
\text { effect }\end{array}$ & $\begin{array}{l}\text { Indirect } \\
\text { effect }\end{array}$ & $\begin{array}{l}\text { Total } \\
\text { Effect }\end{array}$ & Mediating \\
\hline H6 & PBC & INT & ACT & 0.229 & 0.032 & 0.261 & Not Mediating \\
H3m (new path) & SN & INT & ACT & .259 & .238 & .497 & Not Mediating \\
\hline
\end{tabular}

Note. Standardized path estimates are reported.

Table 9 shows the indirect effect estimates to test the mediating effects of revisit intention on each hypothesized paths. Researcher found that revisit intention does not produce any mediating effect in the relationship between perceived behavior control and actual visit behavior (H6). This is shown in Table 9 whereby direct effect is 0.229 , which is more than indirect effect of only 0.032. In contrast, the Generating Model (GM) generates a new indirect path from subjective norm to actual visit behavior. Result of the finding reveals that the revisit intention does not have mediating effect in the relationship between subjective norm and actual visit behavior. This result is supported by Mateos et al. (2002) who examined intention as the mediating factor between exogenous variables and actual behavior. Results of their study asserted that the behavior intention does not have mediating effect. 


\subsection{Overall Comparison between Structural Models}

The results revealed that hypothesized model does not achieve model fit ( $\mathrm{p}$ value $=.000, \mathrm{p}<.001$ ). This implies that hypothesized model was not supported. Even though hypothesized model produced more significant direct impacts, it could not be generalized due to non-achievement of $p$-value $(p<.05)$. Table 10 shows that hypothesized model supports five (5) significant direct impacts while Generating Model (GM) achieved fit model, and supported four direct impacts. Conversely, the path from perceived behavior control to revisit intention is consistently insignificant in Generating Model (GM).The mediating effect of revisit intention in the relationship between perceived behavior control and revisit behavior (H6), was not supported because direct effect valued more than indirect effect. However, indirect effect and direct effect were insignificant. This means that revisit intention does not mediate the relationship between perceived behavior control and revisit behavior. In contrast, the Generating Model (GM) generates a new indirect path from subjective norm to actual visit behavior (H3m). Thus, the result found that the revisit intention does not have the mediating effect in the relationship between subjective norm and actual visit behavior.

Table 10. Comparison between hypothesized model and generating model (M)

\begin{tabular}{|c|c|c|c|c|c|c|c|c|c|}
\hline \multirow[b]{2}{*}{ Hypothesis } & \multirow[b]{2}{*}{ From } & \multirow[b]{2}{*}{ Mediation } & \multirow[b]{2}{*}{ To } & \multicolumn{3}{|c|}{ Hypothesis model } & \multicolumn{3}{|c|}{ Generating Model (GM) } \\
\hline & & & & Estimate & $P$ & $\begin{array}{l}\text { Hypothesis } \\
\text { Asserted }\end{array}$ & Estimate & $P$ & $\begin{array}{l}\text { Hypothesis } \\
\text { Asserted }\end{array}$ \\
\hline H1 & INT & -- & $\mathrm{ACT}$ & 1.848 & $* * *$ & Yes & .979 & $* * *$ & Yes \\
\hline H2 & ATT & -- & INT & .088 & $* * *$ & Yes & .195 & .004 & Yes \\
\hline H3 & $\mathrm{SN}$ & -- & INT & .545 & $* * *$ & Yes & .591 & $* * *$ & Yes \\
\hline H4 & $\mathrm{PBC}$ & -- & INT & .139 & .007 & Yes & .079 & .259 & $N O$ \\
\hline H5 & PBC & -- & $\mathrm{ACT}$ & .706 & $* * *$ & Yes & .549 & .022 & Yes \\
\hline \multirow[t]{2}{*}{ H3a } & $\mathrm{SN}$ & - & $\mathrm{ACT}$ & - & - & - & .629 & .047 & Yes \\
\hline & & & & & & & $\begin{array}{l}\text { Indirect } \\
\text { Effect }\end{array}$ & $\begin{array}{l}\text { Direct } \\
\text { Effect }\end{array}$ & Mediating \\
\hline H6 & PBC & INT & $\mathrm{ACT}$ & - & - & - & .032 & .229 & Not Mediating \\
\hline H3m & $\mathrm{SN}$ & INT & $\mathrm{ACT}$ & & & & .238 & .259 & Not Mediating \\
\hline
\end{tabular}

Among the structural models, Generating Model (GM) achieved the higher square multiple correlation (SMC) or $\left(R^{2}\right)$ Table 11 shows that the Generating Model (GM) explains 53.5\% variance in actual visit behavior; $42.6 \%$ variance in revisit intention. Conversely, the hypothesis model explains $58.9 \%$ variance in actual visit behavior, $51.5 \%$ variance in revisit intention.

Table 11. Comparison between hypothesized model and generating model (GM)

\begin{tabular}{lll}
\hline Goodness-of-fit & $\begin{array}{l}\text { Goodness-of-fit } \\
\text { Hypothesized Model }\end{array}$ & $\begin{array}{l}\text { Goodness-of-fit } \\
\text { Generating Model (GM) }\end{array}$ \\
\hline CMIN & 1202.875 & 52.578 \\
CMIN change & & 1150.297 \\
df & 342 & 45 \\
Df change & & 297 \\
CMIN/df & 3.517 & 1.168 \\
GFI & 0.845 & .983 \\
RMSEA & 0.071 & .018 \\
TLI & 0.864 & .994 \\
CFI & 0.877 & .996 \\
P-value & 0.000 & .204 \\
SMC (R ${ }^{2}$ ) & & \\
actual visit behavior & .589 & .535 \\
Revisit Intention & .515 & .426 \\
\hline
\end{tabular}




\section{Discussion}

This study attempts to examine the goodness of fit of the hypothesized structural model by integrating tourist's attitude, subjective norm, and perceived behavior control. As expected, the hypothesized model does not achieve model fit ( $\mathrm{p}$-value $=0.000, \mathrm{p}<0.001$ ). This implies that hypothesized model is not supported. However, the Generating Model (GM) accomplished model fits and supports four (4) direct effects. Firstly, tourist attitude was found to have a direct significant impact on revisit intention. Past studies have obtained similar result (Celik, 2008; Karami, 2006; George, 2002; Chai \& Pavlou, 2004; Nik Mat \& Sentosa, 2008). Those who have positive attitude about revisit intention are likely to have actual visit behavior, means that the tourists have positive attitude towards visit Jordan in future. Second, subjective norms have a direct significant effect on intention. Chang (1998), Chai and Pavlou (2004) and Nik Mat and Sentosa (2008) have found similar finding. This could imply that families, friends and referent of others could have certain amount of influence on revisit intention rather than on the actual purchasing behavior. This could be especially true amongst international tourists since they may have intentions to actual visit behavior but could be hindered by friends' opinions and involvement. Third, the relationship between Perceived Behavior Control and Revisit Intention is a found to be a positive relationship which has similar to previous findings of Karami's (2006) and Gopi and Ramayah's (2007). Thus, a positive relationship between Perceived Behavior Control and Revisit Intention will increase the possibility of revisit intention. Fourth, the relationship between perceived behavior control and actual visit behavior is also a significant and positive relationship (George, 2004; Fusilier \& Durlabhji, 2005). Finally, revisit intention have a direct significant effect on actual visit behavior. This is supported by numerous past studies (Ajzen, 1985; Ajzen, 1991; Amoroso, 2004; Eagly \& Chaiken, 1993; Kim et al., 2008; George, 2002; Venkatesh, 2000).

In the Generating model (GM), intention was not a mediator between perceived behavior control and actual visit behavior. This means that in most cases international tourists are likely to visit directly once they have the opportunity to visit Jordan. In addition, the Generating Model (GM) generates a new indirect path from subjective norm to actual visit behavior. The result also found that revisit intention does not have mediating effect in the relationship between subjective norm and actual visit behavior. This result supported by Mateos et al. (2002) which examine intention as the mediating effect between exogenous variables and actual behavior. Results from their study asserted that the behavior intention does not mediate the relationship. The study confirmed planned behavior theory (TPB) through the examination of the model fit as an interaction to help better explain, analyze and understand international tourists' behavior.

\section{Suggestion for Future Research}

Future research should investigate the model in a different setting in Jordan such as in middle region or northern region. Therefore, more research needs to be done on these areas and other neighboring regions or countries in order to measure and investigate the international tourists' behavior in the Middle East countries. To have broader view on this country's potential in attracting international tourists, other determinant factors need to be considered in future research such as technological factors i.e., Internet, social-economic factors, and marketing strategies. More importantly, the Ministry of Jordan should focus more on the safety of tourists and the positive image of the country, accessibility to tourist destinations, availability of modern facilities, development of better infrastructures that could help tourists to have a faster access to all religious and historical sites, and tourist destinations. Improving product and service qualities, speed of delivery, and other quality competencies are among the key factors that support service excellence. Subsequently, it will lead to the augmentation of tourists' satisfactions to the destination. This is becoming an ever-increasingly important factor to tourists' satisfaction.

\section{Conclusion}

The research investigates the antecedents of intention/behavior (model TPB). Several direct paths are found to be significantly related to either intention or behavior. The model however fails to assert the mediating effect of intention in the relationship between perceived behavior control and actual visit behavior. In contrast, the Generating Model (GM) is the best model to explain the international tourists' behavior as compared to the Hypothesized Models. Lastly, the Generating Model (GM) generates a new indirect path from subjective norm to actual visit behavior. The result implicates that revisit intention does not have any mediating effect in the relationship between subjective norm and actual visit behavior.

\section{Acknowledgements}

The author is grateful to the Applied Science University, Amman, Jordan, for full financial support granted to this research project (Grant No. Drgs-2013-2014-11). 


\section{References}

Ajzen, I. (1985). From intentions to actions a theory of planned behavior. In J. Kuhl \& J. Beskmann (Eds.), Action Control from Cognition to Behavior (pp. 11-39). New York: Springer.

Ajzen, I. (1988). Attitudes, Personality, and Behaviour. Buckingham: Open University Press.

Ajzen, I. (1991). The theory of planned behavior. Organizational Behavior and Human Decision Processes, 50, 179-211. http://dx.doi.org/10.1016/0749-5978(91)90020-T

Ajzen, I., \& Fishbein, M. (1980). Understanding attitudes and predicting social behavior. Englewood Cliffs, NJ: Prentice Hall.

Amoroso, D. L. (2004). Development of an Instrument to Measure the Acceptance of Internet Technology by Consumers. Hawaii International Conference on System Sciences.

Bagozzi, R. P., \& Dabholar, P. A. (2000). Discursive psychology: an alternative conceptual foundation to the means-end chain theory. Psychology and Marketing, 17, 535-86. http://dx.doi.org/10.1002/(SICI)1520-6793(200007)17:7<535::AID-MAR1>3.0.CO;2-H

Bagozzi, R. P., \& Yi, Y. (1988). On the evaluation of structural equation models. Journal of the Academy of Marketing Science, 16, 74-94. http://dx.doi.org/10.1007/BF02723327

Bang, H., Ellinger, E., Hadimarcou, J., \& Traichal, A. (2000). Consumer concern, knowledge, belief and attitude toward renewable energy: an application of the reasoned action theory. Journal of consumer research, 17(6), 449-68.

Campbell, D. T., \& Fiske, D. W. (1959). Convergent and Discriminant Validation by the Multi-trait, Multimethod Matrix. Psychological Bulletin, 56, 81-105. http://dx.doi.org/10.1037/h0046016

Canniere, M. H., Pelsmacker, P. D., \& Geuens, M. (2008). Relationship Quality and the Theory of Planned Behavior models of behavioral intentions and purchase behavior. Journal of Business Research.

Celik, H. (2008). What determines Turkish customer's acceptance of internet banking? International Journal of Bank Marketing, 26(5), 353-369. http://dx.doi.org/10.1108/02652320810894406

Chai, L., \& Pavlou, P. A. (2004). From 'Ancient to Modern': A Cross-Cultural Investigation of Electronic Commerce Adoption in Greece and the United States. Journal of Enterprise Information Management, 17(6), 416-423. http://dx.doi.org/10.1108/17410390410566706

Chang, M. K. (1998). Predicting unethical behavior: a comparison of the theory of reasoned action of the theory of planned behavior. Journal of Business Ethics, 17(16), 1825-33. http://dx.doi.org/10.1023/A:1005721401993

Coakes, S. J., \& Steed, L. G. (2003). SPSS Analysis without Anguish. Sydney, Australia: John Wiley \& Sons.

Cronin, J. J, Brady, M. K., \& Hult, G. T. (2000). Assessing the Effects of Quality, Value, and Customer Satisfaction on Consumer Behavioral Intentions in Service Environments. Journal of Retailing, 76(2), 193-218. http://dx.doi.org/10.1016/S0022-4359(00)00028-2

Doll, J., \& Ajzen, I. (1992). Accessibility and stability of predictors in the theory of planned behaviour. Journal of Personality and Social Psychology, 63, 754-65. http://dx.doi.org/10.1037/0022-3514.63.5.754

Eagly, A., \& Chaiken, S. (1993). Psychology of Attitudes. NY: Harcourt, Brace Jovanovich.

Fornell, C., \& Larcker, D. (1981). Evaluating structural equation models with unobservable variables and measurement error. Journal of Marketing Research, 48, 39-50. http://dx.doi.org/10.2307/3151312

Fusilier, M., \& Durlabhji, S. (2005). An exploration of student internet use in India, the technology acceptance model and the theory of planned behaviour. Campus-Wide Information Systems, 22(4), 233-246. http://dx.doi.org/10.1108/10650740510617539

George, J. F. (2002). Influences on the intent to make internet purchases. Internet Research: Electronic Networking Applications and Policy, 12(2), 165-180. http://dx.doi.org/10.1108/10662240210422521

George, J. F. (2004). The theory of planned behavior and Internet purchasing. Internet Research, 14(3), 198-212. http://dx.doi.org/10.1108/10662240410542634

Gopi, M., \& Ramayah, T. (2007). Applicability of theory of planned behavior in predicting intention to trade online Some evidence from a developing country. International Journal of Emerging Markets, 2(4), 348-360. http://dx.doi.org/10.1108/17468800710824509 
Hair, J., Black, B., Babin, B., Anderson, R., \& Tatham, R. (2006). Multivariate Data Analysis (6th ed.). Upper Saddle River, NJ: Prentice-Hall.

Howard, R. (2009). Risky business? Asking tourists what hazards they actually encountered in Thailand. Tourism Management, 30(3), 359-365. http://dx.doi.org/10.1016/j.tourman.2008.08.007

Hui, T. K., Wan, D., \& Ho, A. (2007). Tourists' satisfaction, recommendation and revisiting Singapore. Tourism Management, 28, 965-975. http://dx.doi.org/10.1016/j.tourman.2006.08.008

Jarvenpaa, S. L., \& Todd, P. A. (1997). Consumer Reactions to Electronic Shopping on the World Wide Web. Journal of Electronic Commerce, 1(2), 59-88.

Javalgi, R. G., Khare, V., \& Gross, A. C. (2005). An application of the consumer ethnocentrism model to French consumers. International Business Review, 14, 325-44. http://dx.doi.org/10.1016/j.ibusrev.2004.12.006

Karami. M. (2006). Actors influencing Adoption of online Ticketing. Master thesis.

Kim, D. J., Ferrin, D. L., \& Rao, H. R. (2008). A trust-based consumer decision-making model in electronic commerce: The role of trust, perceived risk, and their antecedents. Decision Support Systems, 44, 544-564. http://dx.doi.org/10.1016/j.dss.2007.07.001

Limayen, M., Khalifa, K., \& Firni, A. (2000). What makes consumers buy from Internet? A longitudinal study of online shopping. IEEE Transactions on Systems, Man and Cybernetics, 30(4), 421-432. Lulea University of Technology. http://dx.doi.org/10.1109/3468.852436

Mateos, P., Meilan, J. G., \& Arana, J. M. (2002). Motivational versus Volitional Mediation of Passivity in Institutionalized Older People. The Spanish Journal of Psychology, 5(1), 54-65.

Mathieson, K. (1991). Predicting user intentions: comparing the technology acceptance model with the theory of planned behavior. Information Systems Research, 2(3), 173-91. http://dx.doi.org/10.1287/isre.2.3.173

McIvor, D., \& Paton, D. (2007). Preparing for natural hazards: normative and attitudinal influences. Disaster Prevention and Management, 16(1), 79-88. http://dx.doi.org/10.1108/09653560710729839

Neuman, W. L. (2006). Social research methods: Qualitative and quantitative approaches (6th ed.). Boston: Person Education, Inc.

Nik Kamariah, N. M., \& Sentosa, I. (2008). The integration of theory of planned behavior (tpb) and technology acceptance model in internet purchasing: A structural equation modeling (sem) approach. Proceedings of Applied International Business Conference 2008. College of Business, University Utara Malaysia, Malaysia.

Nunnally, J. C. (1970). Introduction to Psychological Measurement. New York: McGraw-Hill.

Olorunniwo, F., Hsu, M. K., \& Udo, G. F. (2006). Service quality, customer satisfaction, and behavioral intentions in the service factory. Journal of Services Marketing, 20(1), 59-72. http://dx.doi.org/10.1108/09653560710729839

Park, H. S. (2000). Relationships among attitudes and subjective norms: testing the theory of reasoned action across cultures. Communication Studies, 51, 162-75. http://dx.doi.org/10.1080/10510970009388516

Pearce, P. (2005). Tourist behaviour: themes and conceptual scheme. Clevedon: Channel View.

Raman, M., Stephenaus, R., Alam, N., \& Kuppusamy, M. (2008). Information Technology in Malaysia: E-service quality and Uptake of Internet banking. Journal of Internet Banking and Journal of Internet Banking and Commerce, 13(2).

Riley, M., Niininen, O., Szivas, E., \& Willis, T. (2001). The case for process approaches in loyalty research in tourism. International Journal of Tourism Research, 3, 23-32. http://dx.doi.org/10.1002/1522-1970(200101/02)3:1<23::AID-JTR290>3.0.CO;2-M

Shih, Y., \& Fang, K. (2004). The use of a decomposed theory of planned behavior to study Internet banking in Taiwan. Internet Research, 14(3), 213-223. http://dx.doi.org/10.1108/10662240410542643

Smith, J. R., \& Terry, D. J. (2003). Attitude-behaviour consistency: the role of group norms, attitude accessibility and mode of behavioral decision making. European Journal of Social Psychology, 33, 591-608. http://dx.doi.org/10.1002/ejsp.172

Taylor, S., \& Todd, P. A. (1995). Understanding information technology usage: a test of competing models. Information Systems Research, 6(2), 144-76. http://dx.doi.org/10.1287/isre.6.2.144 
Venkatesh, V. (2000). Determinants of perceived ease of use: integrating control, motivation and emotion into the technology acceptance model. Information System Research, 11(4), 342-365. http://dx.doi.org/10.1287/isre.11.4.342.11872

Wong, J., \& Yeh, C. (2009). Tourist Hesitation in Destination Decision Making. Annals of Tourism Research, 36(1), 6-23. http://dx.doi.org/10.1016/j.annals.2008.09.005

\section{Copyrights}

Copyright for this article is retained by the author(s), with first publication rights granted to the journal.

This is an open-access article distributed under the terms and conditions of the Creative Commons Attribution license (http://creativecommons.org/licenses/by/3.0/). 